\title{
Reformulation through governmental norm of the strategic option of Romania regarding the financial - administrative decentralisation
}

\author{
Gabriel Bogdan CHIHAI, Ionel BOSTAN \\ Faculty of Law and Administrative Sciences, \\ "Stefan cel Mare" University of Suceava, Romania \\ chihai.bogdan@gmail.com; ionel_bostan@yahoo.com
}

\begin{abstract}
Through the present paper, the authors propose to bring into the reader's' attention the most relevant legal aspects that relate to the Romanian problematic of administrative decentralisation after adhering to the European Union. With the declared aim to improve the quality of public services and decrease the differences in the economic and social field of less developed areas, even before adhering to the European Union, the necessity of greater involvement of the local public administration authorities in the management of local interests. This involves the transfer of new powers from the central level in favour of the local level, but it also involves the allocation of additional financial resources. Observing a longer period of time (the last year being 2016), we note that a series of powers concerning health, education, youth, child protection, social assistance, local police, etc. were transferred from the central to the county or local level, but we also note that the funds necessary for proper implementation were not transferred. This is the reason why, by starting from other difficulties of the decentralisation process at the level of territorial - administrative units, we ponder upon the milestones of rethinking the strategic options regarding the decentralisation of the Romanian public administration, referencing the most recent General Strategy of Administrative Decentralisation adopted by the Romanian Government.
\end{abstract}

Keywords: The European Chart of Local Autonomy, exclusive/shared/delegated competence, financial resource, administrative capacity, decentralisation strategy.

\section{Democracy of proximity through decentralisation}

In any given country, we have to face "two interest categories: some that have a totally general character regarding the totality of citizens, the whole community, and others that are special to the given locale. In order to harmonise the these two interest categories the state created special legal regimes or institutions, each of them maintaining a more or less appropriate resolution for the given situations" (Negulescu, 1934). But, as it is widely known because it became a absolutely common fact, the public authorities are the first and the most able to discover the needs of the communities and they are the most suited to satisfy said needs in the most appropriate way. A democracy of proximity means, between others, the ability to find solutions, where the problems are and not a "central" level. Decentralisation (giving up components from the central state authorities in favour of local public administration authorities) makes the decision closer to the beneficiaries of the public service, shortens the times needed, makes the process less expensive, and promotes the celerity in finding resolutions for local community manners.

It is also needed to emphasise that decentralisation is also a good way to make local authorities more responsible.

\section{Decentralisation of the Romanian public administration as legal objective}

According to the Romanian Constitution and the Local Public Administration Law nr.215/2001 the local public administration authorities benefit from financial and administrative 
autonomy. The European Chart of Local Autonomy (adopted in Strasbourg at 15 October 1985 and ratified in Romania in 1997) establishes the right of local public authorities to dispose of effective capacity to resolve and manage, in favor of the population, an important part of public affairs. The importance of administrative and financial decentralisation being recognised as essential for the Romanian public administration system (Morariu, 2008; Porfiroiu et al., 2006; Onofrei and Filip, 2004; Onofrei and Bercu, 2005), a law regarding this matter, meant to clarify the principles, rules and institutional framework that would rule the aforementioned process, was adopted even before adhering to the EU.

The abovementioned normative act (PR, 2006a) defined decentralisation as being "the transfer of administrative and financial from the central public administration level to the local public administration", mentioning the fact that this transfer will be made in accordance with the available financial, institutional and human resources that a territorial-administrative unit has, but also the actions performed for the exercise of the lawfully granted competences.

The process of competence transfer from a greater/central authority, to an authority that is smaller, periferic - institutional and geographical - is shown in Figure 1.

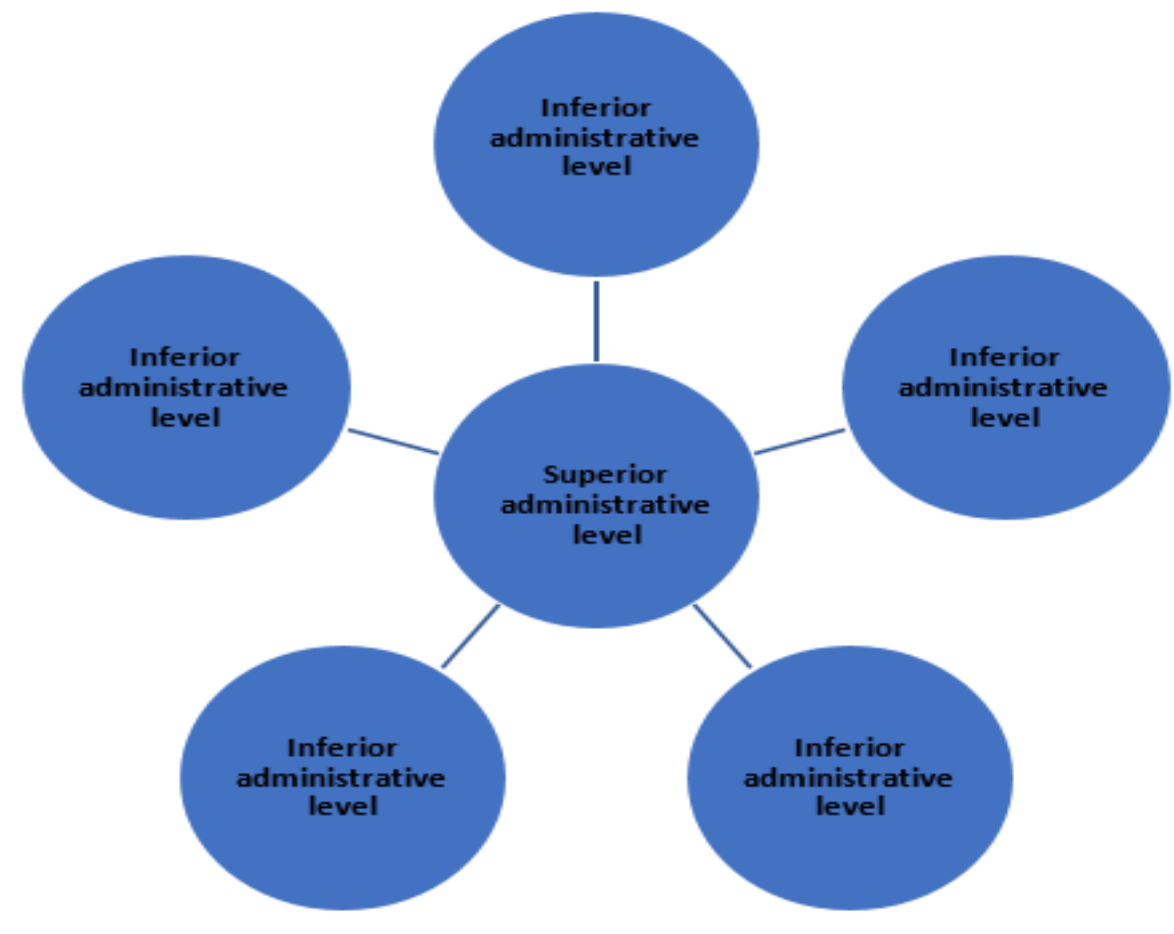

Figure 1. Decentralisation Diagram

Source: http://www.scrigroup.com/legislatie/administratie/Principiul-Descentralizarii84777.php

What we aim to point out is: the higher the resource levels, the more numerous will the gained competences be, from this perspective the administrative capacities being decisive. In this context, the principle of local autonomy cannot be ignored, being given "by the effective right and capacities of local public administration authorities to lawfully manage and resolve the public affairs in the name and interest of the local communities which it represents" (PR, 2001). In all the cases the financing for the local public administration authorities, in order to ensure it's functionality, but also for its development, means the allocation of sums (broken down quotas) from the central budget, maintaining a horizontal and vertical balance of local budgets. Under the financial aspect it is also important to keep in mind that "The transfer by the Government towards the financing and administration of local public administrative authorities, 
of some public expenses, as a result of decentralisation of an activity, al also other new public expenses, is made lawfully only with the provision of the necessary financial resources (...)" (PR, 2006b).

In order to ensure the public services that are of local interest, the local public administration authorities exercise exclusive and shared competences (Table 1).

Table 1. Competences exercised by the local public administrative authorities in order to provide local services of public interest [PR (2006a)]

\begin{tabular}{|c|c|}
\hline Exclusive Competences & Shared Competences \\
\hline $\begin{array}{l}\text { - At communal and city level } \\
\text { o Administration of the public and private } \\
\text { domain of the village or city; } \\
\text { o Administration of local interest traffic } \\
\text { infrastructure; } \\
\text { o Administration of local interest cultural } \\
\text { institutions; } \\
\text { o Administration of local interest public health } \\
\text { units; } \\
\text { o Providing running water; } \\
\text { o Sewage and cleaning of used waters and } \\
\text { rainwater; } \\
\text { o Public lighting; } \\
\text { o Sanitation; } \\
\text { o Primary social services for child protection and } \\
\text { for domestic violence victims; } \\
\text { o Communitary medical assistance; } \\
\text { o Provide medical assistance in some bed } \\
\text { equipped health units; } \\
\text { o Public local transportation; } \\
\text { o Giving out some authorisations and licenses. } \\
\text { - At a county level: } \\
\text { o Administration of local interest airport; } \\
\text { o Administration of the county's local private and } \\
\text { public domain; } \\
\text { o Administration of county interest public health } \\
\text { units; } \\
\text { o Primary social services and specialised for } \\
\text { domestic violence victims; } \\
\text { o Giving out some authorisations and licenses; } \\
\text { o Communitary medical assistance; } \\
\text { o Provide medical assistance in some bed } \\
\text { equipped health units. }\end{array}$ & $\begin{array}{l}\text { - Together with central public administration } \\
\text { authorities: } \\
\text { o Administration of thermal energy produced in central } \\
\text { facilities; } \\
\text { o Building new social homes and homes for young } \\
\text { people; } \\
\text { o Pre Universitary public education, exception being the } \\
\text { special education facilities; } \\
\text { o Public order and safety; } \\
\text { o Giving out social aid for people that are in difficult } \\
\text { situations; } \\
\text { o Preventing and managing crisis situations; } \\
\text { o Primary social assistance services for people with } \\
\text { disabilities; } \\
\text { o Social services for old people; } \\
\text { o Communitary public services for the population } \\
\text { registry; } \\
\text { o Administration of local interest traffic infrastructure at } \\
\text { communal level; } \\
\text { o Covering the expenses for the salaries for the doctors } \\
\text { and nurses but also expenses for medication and health } \\
\text { related materials; } \\
\text { o Managing territory and city planning. } \\
\text { - Together with county level public administration } \\
\text { authorities: } \\
\text { o In case of providing public utilities services through } \\
\text { regional providers. } \\
\text { - County authorities together with central public } \\
\text { administration authorities: } \\
\text { o Administration of county interest traffic infrastructure; } \\
\text { o Special education; } \\
\text { o Medical-social assistance services for people with } \\
\text { social problems; } \\
\text { o Primary social assistance services and specialized for } \\
\text { child protection; } \\
\text { o Social assistance services for people with disabilities; } \\
\text { o Social services for old people; } \\
\text { o Public community service for the population registry; } \\
\text { o County level agricultural consulting; } \\
\text { o Covering the expenses for the salaries for the doctors } \\
\text { and nurses but also expenses for medication and health } \\
\text { related materials. }\end{array}$ \\
\hline
\end{tabular}

Regarding delegated competences from the central; public administration authorities in favour of the local public administration authorities, this refers to the payment of child allowance and the payment of indemnities for adults with special disabilities. By accelerating the competences of the aforementioned nature, in favour of local authorities, it contributes decisively in raising 
the independence and flexibility grade of territorial public administration authorities in establishing the priorities in each community.

\section{The difficulties of the decentralisation process at the level of territorial administrative units. Financial consequences}

The decentralisation process must be made at the level of all territorial administrative units, with regards to the principle of subsidiarity, which is in fact a principle "of social organisation that enables the adjustment of the exercise of competences in a central legal order (European Union or state) and the local legal order (member states of the European Union or infra statal territories)" (Stratan, 2014). The same principle makes a responsibility to be given to the public administration level that is closest to the citizen/taxpayer and which can be fulfilled with efficiency and efficacy (GR, 2017). The process which we are making reference to is only applicable if measures are applied that are meant to "increase the legitimacy of public authorities in designing and fulfilling some strategic objectives on the financial, social and cultural levels, with the effect of modernising the Romanian society" (MDRAP, 2013).

As things have evolved regarding decentralisation, "Theoretically, Romania is already a decentralised state" (Andrei et al., 2006). Thus in order to summarise the professors Tudorel Andrei, Marius Profiroiu and Mihai Turturean, from ASE Bucharest, accounts, they take into consideration arguments like: "the constitution guarantees the free administration of local communities and the lack of tutelage between different levels; successive laws gave to counties and local communities great competences regarding education, health, social assistance, cultural actions and management of local public services." But, the same authors tell us that "the on field reality seems to be left behind, most of the times due to financial reasons". Obviously, between the reasons that affect the fluency of decentralisation, bureaucratic elements are to be remembered, their involvement being explained by the simple existence of the special legal regime for public property goods, which states that if a public property good is transferred from the public domain of the state into the territorial-administrative units, it is to be done at the request of the county/general council of the city Bucharest/local council, through government decision (PR, 1998).

We must also keep in mind that, the fact that in time, the transfer of competences between central and local level was not doubled by the corresponding financial resources/funds. All of these reasons made the decentralisation process at the level of all territorial administrative units to be carried out with difficulty, situation that is mainly associated to the lack of transparency and predictability of the local budget financing systems.

Through the deficiencies that were identified when analysing the way in which the central public administrative authorities have managed decentralisation figure the following (MDRAP, 2017): (i) inexistent or lacking methodological coordination for the exercise of transferred competences; (ii) the transfer of competences to the local public administrative authorities did not take into account their real financial resources and their ability to generate substantial own income, most of the time public services being decentralised without the proper financial resources; (iii) the transfer of competences did not take into account the ability of small territorial administrative units to efficiently exercise the transferred competences; (iv) some goods from the state's and or territorial -administrative units' are still being caught in an unclear legal situation. Solely from the financial point of view, the Romanian administrative system faces with "the limited financial autonomy of territorial units, while the quota of own income from the local taxes is still low, and the local budgets are dependent on more than $50 \%$, on transfers from the state budget" (MDRAP, 2017). 


\section{Rethinking the strategic option regarding decentralisation of Romanian public administration}

In any society, decentralisation brings a series of advantages: from "a more active promotion of some local development instruments that can create jobs and stimulate local development, to a simplified relationship between the citizen and the administrative system (which is directly derived from the principle of subsidiarity), and raising the local public administration's ability to react, as a consequence of a shorter decisional chain" (MDRAP, 2015). Then, according to the same sources: advantages like the following are not to be overlooked: "(i) the increased responsibility in spending public funds, through the transfer of several structures of local interest under the local public administration authorities that are chosen directly through the citizens' vote; (ii) attracting non-repayable european funds by the local public administration authorities, as a result of transferred competences in the process of decentralisation; (iii) the encouragement of competition between local public administration authorities regarding the effects that come from the exercise of new competences; and (iv) a more active involvement of all the local level interest factors in the durable development of local communities, which will lead to the increase of quality in public services".

Because of these advantages alone, Romania is still engaged in a deep process of reforming public administration (MDRAP, 2014), maintaining as main objective the financial and administrative decentralisation. The strategy that was designed specifically for this purpose - preceded by other documents of this type - includes a general objective: "The consolidation of the ability of the local public administration to offer high quality and diversified public services to the citizens, through the transfer of new competences from the central administrative level to public local administration authorities", and two specific objectives: "Realising the transfer of competences from the central to local level which would enable the consolidation of application of the principle of subsidiarity" and "The efficientization of the exercise of decentralised competences in order to ensure quality public services and the expense of public funds" (GR, 2017).

The fact that it is followed by: "amendment/addition/repeal some legal acts of primary level (laws, emergency acts, simple acts) and of secondary level (Government decisions, minister's' orders, etc.) which reglement the competences that are subjected to the decentralisation process", but also "the elaboration of sectoral laws for the materialisation of the competences' transfer, partnered with the transfer of funds necessary for exercising these competences", means that we have to deal with multiple legal implications.

These target all the domains included in the decentralisation process, which are: education - extracurricular activities, youth and sports, culture, tourism, environment, health, agriculture, etc. Under the financial aspect, a benefit may be found in the fact that the decentralisation process, as designed, will be defined by following some principles like (GR, 2017): (i) objectivity (the allocation of funds towards local levels needs to be made based on objective factors), (ii) efficiency (the transferred income system needs to be neutral with regard to the options of public local administration authorities regarding the allocation of resources on sectors and activities) and (iii) predictability (the fiscal yield of the transferred income system needs to be stable and to ensure the realisation of mid-term prognosis).

It can be presumed that the strategy objectives may be reached in the proposed times, because from the start a better use of income in relation with responsibilities is taken into consideration, but also meeting the requirements in relation with "ensuring the completion of the funder's (central administration) objectives, in case of using some conditional transfers and equity (the income transferred to local level varies directly proportional with the financial needs, and indirectly proportional with the fiscal ability)". 


\section{Conclusion}

Starting from the fact that the Romanian administrative system still faces issues like reduced autonomy of territorial units, bearing in mind that some of the decentralisation measures are almost two decades old, in present the strategic option in this matter has been rethought. Being the task of the Romanian Executive, The General Strategy of Administration Decentralisation (2017-2020) aims to bring the decisions a lot closer to the beneficiaries of the public service, to shorten the processing times, to facilitate the money economy and the celerity in finding resolutions for local community manners.

Last, but not the least, it aims to increase responsibility of local public authorities. But, in order to reach these targets, deficiencies should not be identifiable regarding the way in which the central public administration authorities manage decentralisation.

In our opinion, the fact that remains important is that the transfer of new competences, from the central administration levels to the local public administration authorities needs to be doubled by a suitable transfer of funds/financial resources, also imposing, other measures to facilitate the decentralisation process at the level of all administrative territorial units, offering transparency and predictability to the financing systems of local budgets.

\section{Refrences}

[1]. Andrei T., Profiroiu M., Turturean M. (2006). Reforma administrapiei publice locale. Cazul României, Economie teoreticã şi aplicatã, Nr. 2 (497), pp. 55-64, http://store.ectap.ro/articole/38.pdf

[2]. GR (2017). Notă de fundamentare la Hotărârea Guvernului nr. 229/2017 privind aprobarea Strategiei generale de descentralizare, http://gov.ro/ro/print?modul=subpagina\&link=nota-de-fundamentare-hg-nr-229-12-04-2017

[3]. MDRAP (2017). Analiza modului de alocare a competențelor la nivelul administrației publice raportat la calitatea serviciilor publice furnizate cetățenilor, efectuată de Ministerul Dezvoltării Regionale, Administrației Publice și Fondurilor Europene.

[4]. MDRAP (2015). Strategia generală de descentralizare (2015-2016).

[5]. MDRAP (2014). Strategia pentru Consolidarea Administrației Publice 2014-2020, aprobată prin Hotărârea Guvernului nr. 909/2014, http://www.mdrap.ro/userfiles/strategie_adm_publica.pdf

[6]. MDRAP (2013). Expunere de motive la Proiectul Legii privind stabilirea unor măsuri de descentralizare a unor competenţe (...), http://www.mdrap.ro/proiect-de-lege-privind-stabilireaunor-masuri-de-descentralizare-a-unor-competente-exercitate-de-unele-ministere-si-organe-despecialitate-ale-administratiei-publice-centrale-precum-si-a-unor-masuri-de-reforma-privindadministratia-publica

[7]. Morariu A. (2008). Tendinţe europene în managementul funcţiei publice, Editura Artpress, Timişoara.

[8]. Negulescu P. (1934). Tratat de drept administrativ, Bucuresti.

[9]. Onofrei M., Filip Gh. (2004). Elemente de ştiinţa administraţiei, Editura Junimea, Iaşi.

[10]. Onofrei M., Bercu A.M. (2005). Implicaţii financiare ale descentralizării activităţii administrative, Analelele UAIC, Seria Ştiinţe Economice, Tom L/LI, pp. 407-502, http://anale.feaa.uaic.ro/anale/resurse/70\%20Onofrei\%20M,Bercu\%20AImplicatii\%20financiare\%20ale\%20descentralizarii\%20activitatii\%20administrative.pdf

[11]. PR (2006a). Legea-cadru nr. 195 din 22 mai 2006 a descentralizării, http://legislatie.just.ro/Public/DetaliiDocument/72024

[12]. PR (2006b). Legea nr. 273/2006 privind finanțele publice locale, https://lege5.ro/Gratuit/ha3tgnjw/legea-nr-273-2006-privind-finantele-publice-locale

[13]. PR (2001). Legea nr. 215 din 23 aprilie 2001 a administraţiei publice locale, http://www.cdep.ro/pls/legis/legis_pck.htp_act_text?idt=78841

[14]. PR (1998). Legea nr. 213/1998 privind bunurile proprietate publică, cu modificările și completările ulterioare, https://legeaz.net/legea-213-1998-proprietatea-publica/ 
[15]. Profiroiu A., Porfiroiu M., Pradeilles A.A. (2006). Consideraţii privind procesul de descentralizare în România, Administraţie şi management public, No. 7, pp. 32-37, http://ramp.ase.ro/_data/files/articole/7_04.pdf

[16]. Stratan V. (2014). Considerații privind influența principiului subsidiarității asupra participării cetățenilor la viața publică locală, Analele Universităţii de Vest, Timişoara, Seria Drept, No. 1, pp. 96-109, https://drept.uvt.ro/administrare/files/1481048324-7.pdf

\section{РЕФОРМУЛЮВАННЯ УРЯДОМ СТРАТЕГІЧНОГО ВАРІАНТУ РУМУНІЇ ЩОДО АДМІНІСТРАТИВНО-ФІНАНСОВӦ̈ ДЕЦЕНТРАЛІЗАЦІї}

Завдяки цій роботі автори привертають увагу читачів, щодо найбільш актуальних правових питань, пов'язані з випуском адміністративної децентралізації Румунії після вступу до Європейського Союзу. Поставлена метою підвищення якості державних послуг і скорочення нерівності в економічному і соціальному розвитку менш розвинених районів, щодо вступу в СС, була доведена необхідність більш активної участі місцевих органів влади в управлінні місцевими інтересами. Це передбачало передачу нових навичок на центральному рівні на користь місцевого рівня, а також додаткового розподілу фінансових ресурсів. Оглядаючи більш тривалий період часу (останній рік 2016), виявилося, що вони були переведені з центрального на місцевий і повітовий рівнях відносно здоров'я, освіти, молоді, захисту дітей, соціальної допомоги, місцевої поліції і т.д., але необхідні кошти для виконання належної роботи, не були передані. Тому, залежно і від інших труднощів, пов'язаних з процесом децентралізації в адміністративнотериторіальних установ, зупиняється на деяких частинах переосмислення стратегії децентралізації румунського державного управління, що робить особливе посилання на найактуальнішу стратегію, щодо адміністративної децентралізації прийнятого урядом Румунії.

Ключові слова: Свропейська хартія місиевого самоврядування, виняткові / спільні / делеговані повноваэження, фінансові ресурси, адміністративна спроможність, стратегія децентралізаиії.

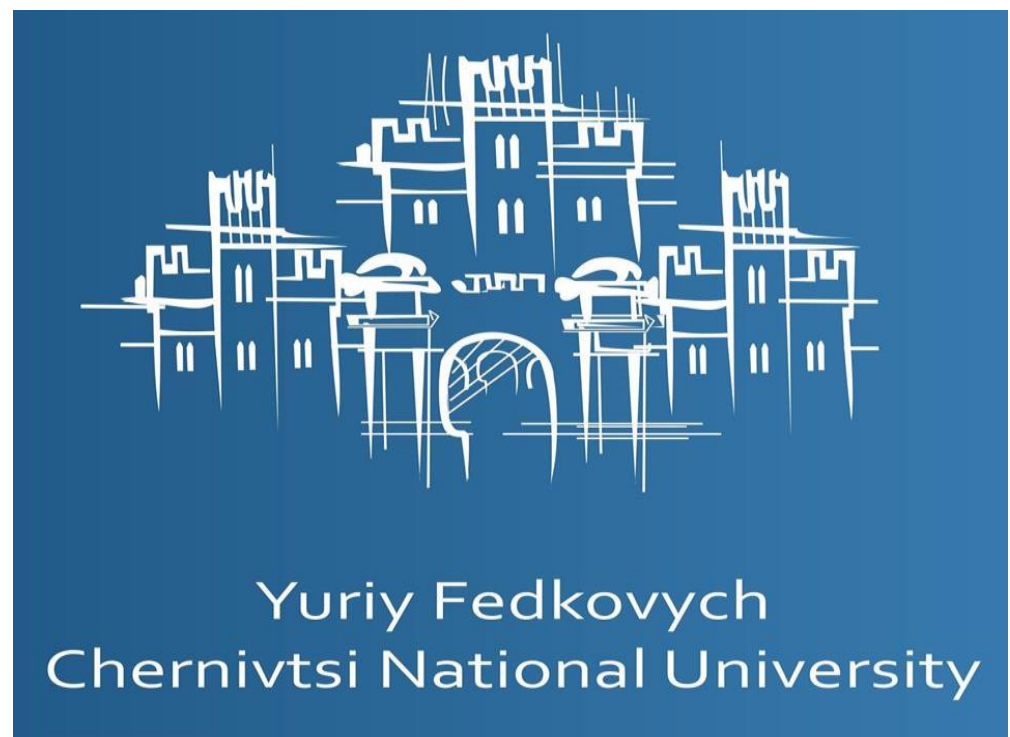

